\title{
PSYCHOLOGICAL WELL-BEING WANITA DEWASA LAJANG (Ditinjau dari Empat Tipe Wanita Lajang menurut Stein)
}

\author{
PSYCHOLOGICAL WELL-BEING FEMALE ADULTS \\ (Judging from the Four Type of Single Women by Stein)
}

Frisca Putri D. W. S.

Fakultas Psikologi, Universitas 17 Agustus 1945 Samarinda

frisca.putri_24@yahoo.co.id

\begin{abstract}
Abstrak: Penelitian ini bertujuan untuk menggambarkan psychological well-being wanita dewasa lajang. Sehingga terdapat 3 hal yang akan diteliti, antara lain yaitu: 1) gambaran psychological wellbeing wanita dewasa lajang dalam menjalani kehidupannya sehari-hari; 2) Faktor-faktor yang mempengaruhi psychological well-being wanita dewasa lajang; 3) Upaya wanita dewasa lajang dalam meraih psychological well-being. Subyek dalam penelitian ini terdiri atas tiga wanita dewasa lajang (belum pernah menikah). Sampel pada penelitian ini dipilih secara purposive sampling dan memenuhi kriteria sebagai berikut: 1) wanita dewasa lajang (belum pernah menikah); 2) Termasuk dalam empat kriteria wanita lajang menurut Stein (Voluntary temporary singles, Voluntary stable singles, Involuntary temporary singles, dan Involuntary stable singles); 3) Termasuk dalam kelompok masa dewasa awal (usia 18-40 tahun), masa dewasa madya (usia 40-60), dan masa dewasa akhir (60meninggal); 4) Berdomisili di kota Samarinda. Penelitian ini menggunakan metode penelitian kualitatif dengan pendekatan fenomenologi. Teknik pengumpulan data yang digunakan peneliti yaitu wawancara, observasi, dan dokumentasi. Hasil dari penelitian ini menyatakan bahwa wanita dewasa lajang dapat menjalani kehidupan yang sama selayaknya wanita yang sudah menikah. Penelitian ini membuktikan bahwa wanita dewasa lajang mampu mencapai psychological well-being.
\end{abstract}

Kata kunci : Psychological well-being, Dewasa, Lajang.

Abstract: This study aimed to describe the psychological well-being single adult women. So there are three things that will be examined, among other things: 1) picture of psychological well-being of women undergoing single adults in their everyday lives; 2) Factors that affect the psychological wellbeing single adult women; 3) Efforts single adult women to achieve psychological well-being. The subjects in this study consisted of three adult women single (never married). Samples have been selected by purposive sampling and meet the following criteria: 1) adult women single (never married); 2) Included in the four criteria of single women by Stein (Voluntary temporary singles, singles stable Voluntary, Involuntary temporary singles and Involuntary stable singles); 3) Included in the group of early adulthood (ages 18-40 years), middle adulthood (ages 40-60), and adolescence (60 died); 4) Based in the city of Samarinda. This study uses qualitative research with phenomenological approach. Data collection techniques the researchers used were interviews, observation, and documentation. The results of this study stated that the single adult female can live the same life should a married woman. This study proves that the single adult women are able to achieve psychological well-being.

Keywords : Psychological well-being, Adult, Single 


\section{PENDAHULUAN}

Perkembangan jaman dan era globalisasi menimbulkan banyak perubahan, terutama terkait dengan pola pikir perempuan usia produktif tentang pernikahan. Di beberapa negara maju, perempuan lebih memilih melajang atau berpasangan tanpa pernikahan, seperti yang terjadi di Amerika Serikat. Banyaknya budaya asing yang masuk Indonesia termasuk salah satu hal yang dapat memicu adanya suatu perubahan.

Salah satu perubahan budaya yang belakangan ini semakin berkembang dan meluas yaitu mengenai wanita dewasa lajang. Beberapa tahun terakhir, terlihat adanya peningkatan terhadap wanita maupun pria dewasa yang masih lajang. Walaupun peningkatannya tidak terlalu signifikan, namun dikhawatirkan akan menurunkan kualitas kebahagiaan maupun tingkat pertumbuhan penduduk di dunia khususnya Indonesia.

Fenomena hidup lajang (single) telah muncul dalam skala global. Dalam perspektif gender, tuntutan menikah jauh lebih berat pada wanita dewasa dari pada pria. Kecenderungan budaya pada masyarakat Indonesia telah membuat wanita didorong untuk menjadi ibu dan istri dalam sebuah keluarga, agar ia dihargai sebagai anggota masyarakat sepenuhnya. Karena budaya tersebut, setiap keluarga akan tetap menyarankan anak wanitanya untuk menikah (Kumalasari, 2007).

Wanita lajang telah menjadi sebuah kategori sosial tersendiri yang dilekati dengan karakteristik yang khas yang seringkali bernada negatif atau "tidak normal" karena akan cenderung dibandingkan dengan kelompok wanita yang sudah menikah yang lebih dipandang "normal" (Septiana, 2013).

Pada umumnya, wanita dewasa awal yang menunda pernikahan terhalang karena belum menemukan pasangan yang tepat, namun ada juga yang hidup melajang karena merupakan pilihan. Seperti yang diungkapkan oleh Feldman (2009), beberapa orang ingin tetap menikmati kebebasan dalam mengambil risiko, bereksperimen, berkeliling dunia, mengejar karir, melanjutkan pendidikan, atau melakukan pekerjaan kreatif. Hurlock (2006) menjelaskan, bahwa selama usia 20-an, tujuan dari sebagian besar wanita yang belum menikah adalah perkawinan. Apabila seorang wanita belum juga menikah pada waktu berumur 30 tahun, mereka cenderung mengganti tujuan dan nilai hidupnya ke arah nilai dan tujuan yang baru dan berorientasi pada pekerjaan, karir, dan kesenangan pribadi.
Terlampau terfokus dengan karir, alhasil kebanyakan wanita kemudian justru melupakan pasangannya, bahkan tidak terpikirkan mengenai pasangan. Terkadang, wanita pun tidak ingin dipandang lemah atau tidak mandiri oleh pria, sehingga ia ingin menghasilkan uang melalui hasil kerja kerasnya sendiri. Namun, hal tersebut pula yang kemudian membuat wanita melupakan halhal lain yang juga sama pentingnya. Terkadang wanita pun memikirkan bahwa memiliki pasangan hanya akan menambah beban di hidup mereka. Terkadang, pembicaraan atau pengalaman dari orang sekitar yang kemudian membuat seorang wanita takut atau bahkan tidak ingin mencoba untuk memiliki pasangan (Kumalasari, 2007).

Di Amerika Serikat, penduduk yang tidak pernah menikah atau memiliki anak, jumlah wanita lebih banyak daripada pria. Selain itu, wanita yang bekerja paruh waktu rata-rata menghasilkan penghasilan lebih banyak Ditambah pula besarnya kesempatan untuk meningkatkan jenjang karir, serta adanya kebebasan untuk mengubah dan melakukan percobaan dalam pekerjaan dan gaya hidup. Adanya fenomena inilah yang membuat para wanita bekerja tetap mempertahankan kelajangannya, sebab mereka berpikir pernikahan hanya akan menjadi batu sandungan dalam berkarir (DePaulo \& Morris, 2008).

Di Indonesia, hasil sensus penduduk pada tahun 2010 yang dilaporkan oleh Badan Pusat Statistik (BPS) menunjukkan, bahwa wanita berusia 30-54 yang belum menikah berjumlah 1.418.689 orang, atau sekitar $4,1 \%$ dari total jumlah wanita Indonesia yang berada pada rentang usia yang sama. Menurut Data BPS pada tahun 2013, persentase untuk wanita yang belum menikah pada rentang usia 25-44 adalah sebesar $10,83 \%$, dan untuk rentang usia 45-59 adalah sebesar $2,58 \%$. Sedangkan, untuk wanita yang belum menikah pada usia yang lebih dari 60 tahun adalah sebesar $1,11 \%$.

Batas usia menikah sudah ditentukan oleh Undang-undang Perkawinan. Pada Undangundang Perkawinan tahun 1974, usia minimum seorang perempuan untuk menikah adalah 16 tahun. Sedangkan untuk pria, 18 tahun. Namun menurut BKKBN, akan lebih siap jika seorang wanita menikah di atas usia 20 tahun. Usia menikah ideal untuk perempuan di Indonesia adalah 20-35 tahun dan 25-40 tahun untuk pria. BKKBN menjelaskan, pada umur 20 tahun ke atas, organ reproduksi perempuan sudah siap mengandung dan melahirkan. Selain itu, Lewis \& Moon (1997) menyatakan bahwa pada tahun 1960-an, wanita yang sudah berusia 25 tahun 
masih lajang dipandang negatif oleh masyarakat. Berbeda pada masa tahun 1980-an, lajang mulai dianggap sebagai salah satu gaya hidup (dalam Nanik, 2015).

Setiap orang bisa menikmati hidup dan berfungsi secara sosial. Jika alasan menikah hanya untuk kebutuhan status, maka pilihan tersebut bisa menimbulkan efek negatif. Tidak hanya itu, pernikahan yang berlangsung hanya dikarenakan status juga dapat membuat seseorang tidak lagi bisa menikmati hidup sepenuhnya. Sebab, menikah adalah pilihan penting dan harus bersedia untuk berkomitmen selamanya.

Dari fenomena yang telah dijabarkan di atas, menarik minat peneliti untuk mengkaji lebih jauh mengenai gambaran psychological well-being wanita dewasa lajang dalam menjalani kehidupannya sehari-hari dengan judul, "Psychological well-being Wanita Dewasa Lajang".

\section{METODE PENELITIAN}

\section{A. Metode dan Alasan Menggunakan Metode Kualitatif}

Penelitian ini dilakukan dengan menggunakan metode penelitian kualitatif. Jenis penelitian ini akan mampu menangkap berbagai informasi kualitatif yang lebih rinci dan mendalam, dibandingkan pernyataan jumlah atau frekuensi dalam bentuk angka. Metode penelitian kualitatif yang sesuai dengan penelitian ini adalah dengan pendekatan fenomenologi.

Fenomenologi tidak berasumsi bahwa peneliti mengetahui arti sesuatu bagi orangorang yang sedang diteliti oleh mereka. Mereka berusaha masuk ke dalam dunia konseptual para subyek yang ditelitinya sedemikian rupa sehingga mengerti apa dan bagaimana suatu pengertian yang dikembangkan oleh mereka di sekitar peristiwa dalam kehidupannya sehari-hari. Inquiry fenomenologis memulai dengan diam.

Oleh karena itu, sesuai dengan metodologi kualitatif deskriptif yang telah dipaparkan menurut beberapa ahli, maka peneliti dapat mengumpulkan data secara lebih mendalam dan terinci. Peneliti akan menyajikan sesuai dengan apa yang dilihat melalui observasi di lapangan, maupun apa yang dipaparkan secara langsung melalui wawancara oleh subyek itu sendiri. Disini, peneliti bersifat sebagai orang yang netral. Peneliti tidak menimbulkan persepsi ataupun asumsi apapun mengenai subyek, sehingga peneliti terfokus meneliti dan menggambarkan keadaan subyek sesuai dengan apa yang terjadi dan ditemukan oleh peneliti di lapangan, tanpa adanya hal yang dikurangi ataupun dilebih-lebihkan.

\section{B. Tempat Penelitian}

Penelitian ini dilakukan di Ibukota Provinsi Kalimantan Timur, yaitu kota Samarinda. Pada penelitian ini, peneliti menggunakan tiga orang subyek, dengan tempat tinggal yang jaraknya cukup jauh antara subyek A, subyek B, maupun subyek C. Subyek A dan B bertempat tinggal di kecamatan Samarinda Ulu, kelurahan Air Putih, dan subyek $\mathrm{C}$ bertempat tinggal di kecamatan Sambutan, kelurahan Sambutan.

\section{Unit Analisis}

Menurut beberapa penjabaran yang telah dijelaskan sebelumnya, maka dapat disimpulkan bahwa psychological well-being wanita dewasa lajang yaitu kesejahteraan psikologis yang dilihat melalui seorang wanita dewasa yang belum atau tidak pernah menikah, namun dapat menerima keadaan dirinya. Selain itu wanita lajang tersebut juga mampu mengoptimalkan potensi-potensi yang ada pada dirinya secara maksimal, sehingga ia berguna bagi dirinya sendiri maupun bagi orang lain dalam menjalani kehidupannya sehari-hari, walaupun tengah mengalami perubahan-perubahan fisik, psikologis, maupun berkurangnya kemampuan reproduktif. Kriteria wanita dewasa lajang tersebut berada pada rentang usia 25-60 tahun, yang pernah atau sedang bekerja, termasuk dalam empat tipe wanita dewasa lajang menurut Stein, serta berdomisili di kota Samarinda.

\section{Sampel Sumber Data}

Dalam teknik penelitian ini, sampel sumber data dipilih secara purposive sampling. Teknik purposive sampling dilakukan dengan cara mengambil subyek bukan didasarkan atas strata, random atau daerah tetapi didasarkan atas dasar tujuan tertentu (Arikunto, 2002).

Karena itu, pada pengambilan data, peneliti harus menyamakan sifat-sifat tertentu dan ada sangkut paut dengan ciri-ciri spesifik yang ada pada populasi, yang kemudian dijadikan kunci untuk pengambilan sampel (Cholid, 2007). Sampel sebagai sumber data 
atau sebagai subyek sebaiknya memenuhi kriteria sebagai berikut: wanita yang masih lajang (belum pernah menikah) berada pada rentang usia 25-60 tahun, masuk dalam kelompok masa dewasa awal (usia 18-40 tahun), masa dewasa madya (usia 40-60), dan masa dewasa akhir (60-meninggal), termasuk dalam empat kriteria wanita lajang menurut Stein (Voluntary temporary singles, Voluntary stable singles, Involuntary temporary singles, dan Involuntary stable singles).

\section{E. Teknik Pengumpulan Data}

Teknik pengumpulan data dalam penelitian ini yang digunakan peneliti adalah observasi, wawancara, dan dokumentasi

\section{F. Teknik Analisis Data}

Metode analisis data yang digunakan dalam penulisan karya ilmiah ini adalah analisis deskriptif kualitatif, dimana peneliti selain mengolah dan menyajikan data, juga melakukan analisis data kualitatifnya. Hal ini dimaksudkan agar dapat menyinergikan antara beberapa data yang telah didapatkan dengan berbagai literatur maupun data-data lain yang telah dipersiapkan.

Menurut Sugiyono (2014), langkahlangkah peneliti dalam menganalisis data adalah dengan cara sebagai berikut: Data Reduction (Reduksi Data), Conclusion Drawing (Verifikasi), Data Display (Penyajian Data).

\section{G. Pengujian Keabsahan Data}

Dalam penelitian ini pemeriksaan keabsahan datanya menggunakan teknik triangulasi, yakni teknik pemeriksaan keabsahan data yang memanfaatkan sesuatu yang lain di luar data itu untuk keperluan pengecekan atau sebagai pembanding terhadap data itu. Teknik triangulasi yang paling banyak digunakan ialah memeriksakan melalui sumber lainnya (Moleong, 2006). Proses penelitian ini menggunakan tiga teknik keabsahan data yaitu instrument, pengamatan yang teliti, dan triangulasi

\section{PENELITIAN DAN PEMBAHASAN}

\section{A. Setting Penelitian}

Penelitian ini menggunakan metode kualitatif dan pendekatan deskriptif. Metode kualitatif sering disebut metode penelitian naturalistik karena penelitiannya dilakukan pada kondisi yang alamiah (natural setting). Pada penelitian kualitatif peneliti dituntut dapat menggali data berdasarkan apa yang diucapkan, dirasakan, dan dilakukan oleh sumber data. Pada penelitian kualitatif peneliti bukan sebagaimana seharusnya apa yang dipikirkan oleh peneliti tetapi berdasarkan sebagaimana adanya yang terjadi di lapangan, yang dialami, dirasakan, dan dipikirkan oleh sumber data. (Sugiyono, 2012)

\section{B. Hasil Penelitian}

\section{Deskripsi Subyek Penelitian}

a. Subyek satu (L. S. F.)

Selama peneliti melakukan penelitian, L. S. F. merupakan subyek yang pertama kali bersedia meluangkan waktunya untuk peneliti observasi maupun wawancara.

Subyek satu adalah seorang wanita dewasa lajang yang berusia 55 tahun. Subyek satu adalah anak ke-4 dari tujuh bersaudara. Ia bekerja sebagai PNS (pegawai negeri sipil) di kota Samarinda. Subyek memiliki tempat tinggal di Jl. Ir. H. Juanda, kecamatan Samarinda Ulu. Sebelumnya, di rumahnya tersebut subyek tinggal bersama dengan ibunya, seorang keponakan laki-laki, dan seorang keponakan perempuan. Namun, semenjak ibunya meninggal dunia, dan keponakan laki-lakinya tersebut berumah tangga lalu memiliki rumah sendiri, maka subyek satu hanya tinggal bersama dengan keponakan perempuannya yang bernama $\mathrm{N}$.

Dalam melakukan proses observasi maupun wawancara, peneliti sangat berhati-hati, menghindari agar subyek tidak merasa tersinggung dan tidak nyaman terhadap peneliti. Peneliti mewawancarai subyek sebanyak dua kali, dalam setiap proses awal wawancara terlihat jelas bahwa subyek menjawab pertanyaan dengan sangat hati-hati, bahkan pada beberapa pertanyaan tertentu subyek sempat terdiam terlebih dahulu sebelum menjawab pertanyaan yang diberikan oleh peneliti. Setelah proses wawancara berjalan beberapa menit, perlahan subyek berbicara

Frisca Putri D.W. S.


dengan cukup lancar dan bercerita cukup panjang dan lebar mengenai pertanyaan yang diberikan oleh peneliti, namun subyek adalah wanita yang sangat ramah dan baik, sehingga mempermudah peneliti dalam melakukan wawancara.

\section{b. Subyek dua (B. K.)}

Selama peneliti melakukan penelitian, B. K. merupakan subyek kedua yang bersedia meluangkan waktunya untuk peneliti observasi maupun wawancara. Subyek bersedia diwawancarai di rumahnya pada beberapa hari sebelum Hari Raya Idul Fitri. Selama proses observasi dan wawancara pada subyek dua, subyek selalu menjawab pertanyaan yang diberikan oleh peneliti dengan sangat jelas, santai, dan terstruktur. Untuk melakukan pendekatan kepada subyek dua pun tidak terlalu lama dan sulit. Hal tersebut dikarenakan subyek dua yang memiliki sifat ramah, mudah bergaul, dan juga mudah menyesuaikan diri. Subyek dua memiliki cukup banyak pengalaman dan ilmu pengetahuan yang juga cukup luas. Tidak hanya itu, subyek dua juga cukup mudah dalam memberikan keterangan atas pertanyaan yang diberikan peneliti, hanya saja pada saat berjalannya wawancara terkadang peneliti harus pintar dalam menyiasati jalannya wawancara, sebab jika tidak demikian maka subyek seringkali menjawab pertanyaan yang dilengkapi dengan cerita yang tidak termasuk dalam sasaran peneliti. Pada tiap pertanyaan yang membahas mengenai orangtua, subyek selalu saja merendahkan volume dan intonasi suaranya, bahkan matanya pun selalu saja berkaca-kaca seraya memberikan penjelasan tersebut.

$\mathrm{B}$ adalah seorang wanita dewasa lajang yang berusia 63 tahun. B adalah anak ke-1 dari sembilan bersaudara. Kini, B adalah seorang pensiunan PNS (Pegawai Negeri Sipil) di kota Samarinda, sebelumnya wanita berkulit sawo matang yang memiliki rambut panjang dan ikal tersebut bekerja pada bidang kesehatan, namun dikarenakan subyek seringkali mengalami sakit maka ia pensiun dini. Subyek memiliki tempat tinggal di Jl. Sultan Sulaiman, kecamatan Sambutan. Subyek telah memiliki rumah pribadi dan hanya tinggal seorang diri. Keseharian subyek adalah di rumah, hanya saja terkadang ia juga menginap di rumah keluarganya yang juga berada di kota Samarinda maupun di luar kota Samarinda. Subyek cukup sering mengunjungi rumah para saudaranya, terutama jika ada salah satu saudaranya yang sedang sakit ataupun akan melaksanakan suatu acara.

\section{c. Subyek tiga (I. S.)}

Selama peneliti melakukan penelitian, I. S. Merupakan subyek ketiga sekaligus terakhir yang bersedia meluangkan waktunya untuk peneliti observasi maupun wawancara. I. S. Adalah seorang wanita dewasa lajang yang berusia 33 tahun. I. S. Adalah anak ke-4 dari lima bersaudara. Ia bekerja sebagai PNS (Pegawai Negeri Sipil) di kota Samarinda. Subyek memiliki tempat tinggal di Jl. Anggur, kecamatan Samarinda Ulu. Subyek tinggal bersama dengan tante dan kedua putri angkatnya. Kesehariannya, subyek bekerja sejak pagi hingga sore, bahkan hingga malam hari. Subyek bersedia untuk diwawancarai oleh peneliti setelah ia pulang dari bekerja. Awalnya, peneliti cukup kesulitan dalam mengatur janji dengan subyek agar dapat mewawancarainya, sebab ia memiliki pekerjaan yang cukup padat. Setelah beberapa kali mengatur jadwal dengan subyek, hingga akhirnya subyek bersedia meluangkan waktunya dengan sedikit kesempatan yang ia miliki dan membuat janji untuk bertemu di cafe dalam sebuah pusat perbelanjaan yang ada di Samarinda. Tidak hanya itu, dalam proses berjalannya wawancara, subyek telah meminta izin kepada peneliti agar dapat mengizinkannya mengangkat ponselnya jika berdering. 
Selama proses berjalannya wawancara, subyek meminta izin kurang lebih sebanyak empat kali untuk menjawab ponselnya. Dan selama beberapa kali peneliti mengizinkan subyek untuk menjawab ponselnya, peneliti juga membuktikan sifat subyek yang menyatakan bahwa dirinya tidak dapat menahan emosinya. Meskipun keadaan disekitarnya terdapat beberapa orang asing, namun subyek tidak terlalu memperdulikannya dan tetap terus menumpahkan emosinya kepada anak angkatnya melalui ponselnya tersebut.

\section{Hasil Analisis Data}

\begin{abstract}
Hasil analisis data berisi tentang uraian interpretasi penulis atas keseluruhan data penelitian yang diperoleh untuk menjawab pertanyaanpertanyaan yang diajukan sebelumnya dalam fokus penelitian. Menurut hasil dari observasi dan wawancara maka dapat dijabarkan berdasarkan beberapa beberapa dimensi, antara lain yaitu seperti:
\end{abstract}

\section{a. Dimensi penerimaan diri}

Kesimpulan dimensi penerimaan diri dari ketiga subyek rata-rata menunjukkan bahwa mereka sudah cukup mampu melakukan penerimaan diri dengan sangat baik. Ketiga subyek dinilai sangat mampu untuk menyadari dan menerima diri mereka apa adanya, baik dalam hal kekurangan maupun kelebihan. Tidak hanya itu, ketiga subyek juga dinilai sudah cukup mampu untuk mengevaluasi diri secara positif terhadap dirinya yang sekarang maupun dirinya di masa lalu.

\section{b. Dimensi hubungan positif dengan orang lain}

Kesimpulan dimensi hubungan positif dengan orang lain dari ketiga Subyek rata-rata menunjukkan bahwa mereka cukup mampu beradaptasi dengan optimal, baik dalam lingkungan keluarga maupun lingkungan sekitar. Subyek mampu mengelola hubungan interpersonal secara emosional dengan baik, hanya saja kebanyakan dari Subyek menjalin hubungan positif dengan pria namun hanya sebatas teman dekat, dan tidak lebih. Bahkan, kedua Subyek tidak pernah berpacaran samasekali. Subyek satu masih kurang mampu dalam menjalin hubungan positif dengan lingkungan sekitar, namun memiliki hubungan yang baik dengan lingkungan keluarga. Sebaliknya, subyek tiga masih kurang mampu dalam menjalin hubungan positif dengan lingkungan keluarga, namun memiliki hubungan yang baik dengan lingkungan sekitar.

\section{c. Dimensi penguasaan terhadap lingkungan}

Kesimpulan dimensi kemandirian dari ketiga subyek menyimpulkan bahwa subyek sudah cukup mampu mandiri dalam kehidupannya seharihari. Ketiga subyek seringkali mampu melakukan berbagai aktifitasnya seorang diri, tidak tergantung dengan orang lain, juga mandiri dalam hal perekonomiannya. Dari ketiga subyek hanya subyek satu saja yang masih kurang mandiri, sebab dalam kesehariannya ia tidak tinggal seorang diri, sehingga untuk bepergian dan ada hal yang ia butuhkan dapat dibantu oleh keponakan yang tinggal di rumahnya tersebut.

\section{d. Dimensi tujuan hidup}

Kesimpulan dimensi penguasaan terhadap lingkungan dari ketiga subyek rata-rata menunjukkan bahwa mereka sudah cukup mampu dalam menguasai lingkungan. Subyek mampu mengatur kehidupan, efektif dalam lingkungan sekitar, memodifikasi lingkungannya agar dapat mengelola kebutuhan dan tuntutan-tuntutan dalam hidupnya, mengendalikan lingkungan secara kreatif, serta berfungsinya aspek psikologisnya secara positif. Hampir semua kemampuan dalam dimensi penguasaan terhadap lingkungan mampu terpenuhi oleh kedua subyek, terkecuali pada subyek satu, sebab ia 
masuk kurang mampu melakukan penguasaan lingkungan dengan baik.

\section{e. Dimensi pertumbuhan pribadi}

Kesimpulan dimensi tujuan hidup dari ketiga subyek rata-rata menunjukkan bahwa mereka telah mampu memaknai tujuan hidup di berbagai usaha dan kesempatan. Subyek memiliki tujuan dan keyakinan bahwa hidupnya berarti, dan mengarah pada kehidupan yang bermakna pencapaian mimpi-mimpi yang diharapkan tiap individu dalam masa depannya. Salah satu dari ketiga subyek, yaitu subyek tiga masih kurang mampu memaknai tujuan hidup, sebab ia masih kurang mampu membuat perencanaan mengenai kehidupannya di masa yang akan datang. Namun, ketiga subyek ratarata menyatakan bahwa tujuan hidup mereka lebih kepada kebahagiaan akhirat.

\section{f. Latar belakang subyek}

Kesimpulan dimensi pertumbuhan pribadi ketiga subyek rata-rata menunjukkan bahwa mereka masih kurang optimal dalam memenuhi pertumbuhan pribadinya. Di antara ketiga subyek, hanya subyek dua yang terlihat dapat memenuhi pertumbuhan pribadinya secara optimal. Selain itu, subyek dua juga mampu mencapai suatu karakteristik yang telah diciptakan sebelumnya, tumbuh sebagai seorang yang berkualitas, keterbukaan untuk mengalami sesuatu, serta merealisasikan potensi yang dimiliki. Sedangkan, bagi kedua subyek lainnya hanya merasa bahwa kepuasan hidupnya cukup terpenuhi namun masih kurang dalam melakukan aktualisasi diri. Meskipun demikian, dari ketiga subyek samasama memiliki kualitas hidup yang cukup baik.

\section{g. Latar belakang subyek}

Kesimpulan dua dari kedua subyek memiliki latar belakang keluarga yang serupa, yaitu keluarga yang harmonis dan selalu menjadi panutan kedua subyek. Sebaliknya, pada subyek tiga yang merasa bahwa ia berasal dari keluarga yang kurang harmonis, hal tersebut diperkuat oleh pernyataan subyek yang mengatakan bahwa ia tidak suka menghabiskan waktu dengan keluarga, tidak betah di rumah, terbiasa menyaksikan pertengkaran yang ada dalam keluarganya, dan sebagainya. Namun, dari ketiga subyek, mereka memiliki latar belakang pekerjaan yang sama, yaitu bekerja sebagai PNS, hanya saja salah satu subyek kini telah pensiun dan juga memiliki latar belakang penyakit yang cukup kompleks.

\section{h. Faktor penyebab lajang}

Kesimpulan faktor penyebab lajang dari ketiga subyek beragam, meskipun mereka sama-sama mengatakan bahwa alasan masih lajang hingga saat ini adalah karena belum menemukan jodoh. Dua dari tiga subyek sama-sama belum pernah berpacaran, sedangkan untuk subyek tiga pernah berpacaran sebanyak dua kali. Salah satu dari tiga subyek memiliki persepsi negatif mengenai pria maupun pernikahan, sedangkan dua diantaranya memiliki persepsi netral mengenai pernikahan hanya saja terlalu merasa nyaman dengan kehidupan yang telah ia jalani saat ini dengan kesendiriannya tersebut. Ketiga subyek sama-sama merasa khawatir akan keterikatan jika suatu saat melakukan pernikahan. Salah satu subyek, tepatnya pada subyek satu kini memutuskan untuk tidak menikah.

\section{Pembahasan}

Dari ke tiga dinamika psychological wellbeing maka dapat disimpulkan bahwa ketiga subyek memiliki latar belakang melajang yang berbeda-beda, namun tetap memiliki tujuan hidup yang cukup sejalan. Hasil penelitian dari ketiga subyek menunjukkan, bahwa meskipun tidak /belum menikah (lajang) namun mereka dapat memenuhi psychological well-being. Ketiga subyek meningkatkan psychological well-being dengan cara tetap menjalin hubungan positif dengan lingkungan sekitar, maupun dengan 
Allah SWT. Status lajang tidak selamanya membuat kehidupan seorang wanita menjadi tidak lebih baik dari kehidupan wanita yang telah menikah/memiliki pasangan, sebab dalam kesehariannya wanita dewasa lajang dapat berguna bagi dirinya sendiri maupun bagi orang lain.

\section{KESIMPULAN}

Berdasarkan hasil laporan penelitian sebelumnya, maka pada bab ini peneliti dapat menyimpulkan bahwa psychological well-being wanita dewasa lajang yaitu kesejahteraan psikologis yang dilihat melalui seorang wanita dewasa yang belum atau tidak pernah menikah namun dapat menerima keadaan dirinya tersebut serta mampu mengoptimalkan potensi-potensi yang ada pada dirinya secara maksimal, sehingga ia berguna bagi dirinya sendiri maupun bagi orang lain dalam menjalani kehidupannya sehari-hari, walaupun tengah mengalami perubahanperubahan fisik, psikologis, maupun berkurangnya kemampuan reproduktif.

Subyek satu merupakan wanita lajang tipe voluntary stable single, sebab ia adalah wanita yang tidak pernah menikah, memutuskan untuk tidak menikah lagi, hidup bersama dengan keponakannya dalam rumah pribadinya, namun tidak memiliki keinginan untuk menikah. Peneliti menarik kesimpulan bahwa subyek satu tidak menikah berdasarkan pernyataan yang diutarakan secara langsung oleh subyek satu

Subyek dua merupakan wanita lajang tipe involuntary stable singles, sebab ia adalah wanita yang tidak pernah menikah dan memiliki harapan untuk menikah. Subyek dua menyatakan bahwa dirinya tidak berani jika suatu saat Allah berkehendak lain dan memberikannya jodoh, namun subyek juga telah mampu untuk menerima kemungkinan akan hidup sendiri.

Subyek tiga merupakan wanita lajang tipe voluntary temporary singles, sebab ia adalah wanita yang tidak pernah menikah dan memiliki keinginan untuk menikah, namun tidak berusaha mencari pasangan secara aktif, lebih memprioritaskan kegiatan lain, seperti berkarir, mencari kepuasan hidup, dan mendekatkan diri kepada Allah.

Ketiga subyek merasa bahwa dengan status lajangnya saat ini dapat membuat mereka lebih memiliki banyak waktu untuk memperkuat amal ibadah. Beragam, stigma yang ada di lingkungan sekitar tidak terlalu menjadi hambatan dalam keseharian subyek, bahkan dibalik stigma negatif mengenai wanita dewasa lajang, terdapat pula Jurnal Motiva dukungan sosial untuk tetap mempertahankan status lajangnya tersebut. Berdasarkan penelitian yang telah dilakukan, maka dapat disimpulkan bahwa wanita dewasa lajang mampu mencapai psychological well-being dalam kehidupannya sehari-hari.

\section{DAFTAR PUSTAKA}

Arikunto, Suharsimi. 2002. Prosedur penelitian. Jakarta: Rineka Cipta.

Cholid, Narbuko \& Achmadi, A. 2007. Metode penelitian. Jakarta: Bumi Aksara.

Dahlan, M. Djawad, 2001. Psikologi perkembangan anak dan remaja. Bandung: Remaja Rosda Karya.

Dariyo, 2003. Psikologi perkembangan dewasa muda. Jakaeta: Grasindo

DeGenova, M. K. 2008. Intimate relationships, marriages, and families $\left(7^{\text {th }} \mathrm{ed}\right)$. Boston: McGraw-Hill.

DePaulo, B. M. \& Morris, W. L. 2008. Singles in society and in science. Journal Psychological Inquiry, 16(2), 57-83.

DePaulo, B. M. \& Morris, W. L. 2006. The unrecognized stereotyping and discrimination against singles. Current Directions in Psychological Science, 15(2), 251-254.

Fakultas Psikologi 2014. Pedoman penulisan skripsi fakultas psikologi. Samarinda: Universitas 17 Agustus 1945 Samarinda.

Hapsari, P., Nisfiannoor, M. \& Murmanks, A. W. 2007. Konflik wanita Jawa yang masih melajang di masa dewasa madya. Jurnal Arkhe, 12(3).

Hoyer, W. J. \& Roodin, P. A. 2003. Adult development and aging $\left(5^{\text {th }} \mathrm{ed}\right.$.) NewYork: McGraw-Hill.

Hwo-Ho, J. 2015. The problem group? Psychological wellbeing of unmarried people living alone in the republic of Korea. Demographic Research: Journal of Population Asciens, 32, 1299-1328.

Hurlock, E. B. 2006. Psikologi perkembangan suatu pendekatan sepanjang rentang Frisca Putri D.W. S. 
kehidupan (5 $5^{\text {th }}$ ed.) Alih bahasa Istiwidayanti dan Soedjarwo. Jakarta: Erlangga.

Indriana, Y., Indrawati, E. S. \& Ayuaningsih, A. 2007. Persepsi wanita karir lajang tentang pasangan hidup (Studi kualitatif fenomenologis di Semarang). Jurnal Ilmiah Untar Arkhe, 12(2).

Jayalaksana, Naomi. (2010, 15 Desember). Kenapa ingin melajang? [on-line]. Diakses pada tanggal 23 Maret 2016 dari http://assyami.blogspot.co.id/2010 /12/ kenapa-ingin-melajang.html

Kartono, Kartini. 2006. Psikologi wanita 1: Mengenal gadis remaja dan wanita dewasa. Bandung: Mandar Maju.

Kumalasari, D. 2007. Single professional women sebagai fenomena gaya hidup baru di masyarakat Yogyakarta (Studi kasus: kabupaten Sleman). Jurnal Pendidikan Sejarah FISE UNY [on-line]. Diakses pada tanggal 20 Maret 2016 dari http://staff.uny.ac.id/sites/default/files/penel itian/Dr.\%20Dyah

\%20Kumalasari,\%20M.Pd./SINGLE\%20P

ROFESSIONAL\%20WOMEN\%20SEBAG

AI\%20FENOMENA\%20GAYA\%20HIDU P\%20BARU\%20DI\%20MASYARAKAT \%20YOGYAKARTA.pdf.

Kurniati, G., Hartati \& Nanik. 2013. Psychological well-being pada pria lajang dewasa madya. Jurnal Ilmiah Universitas Surabaya, 2(3), 1-17.

Kurniasari K. \& Leonardi, T. 2013. Kualitas perempuan lanjut yang melajang. Jurnal Psikologi Pendidikan dan Perkembangan, 2(2), 152-159.

Lazarus, R. S. 2006. Emotions and interpersonal relationships: Toward a person-centered conceptualization of emotions and coping. Journal of Personality, 74, 9-46.

Moleong, J. Lexy. 2006. Metodologi penelitian kualitatif. Bandung: PT Remaja Rosda Karya.
Moleong, J. Lexy. 2009. Metodologi penelitian kualitatif (Edisi Revisi). Bandung: PT Remaja. Rosda Karya.

Moleong, J. Lexy. 2011. Metode penelitian kualitatif (Edisi Revisi). Bandung: PT. Remaja Rosdakarya.

Nanik. 2015. Aku perempuan yang berbeda dengan perempuan lain di jamanku: Aku bisa bahagia meski aku tidak menikah. Proceeding Seminar Nasional (Positive Psychology). Surabaya: Universitas Katolik Widya Mandala Surabaya.

Papalia, D. E, Olds, S. W. \& Feldman, R. D. 2009. Human development. $\left(11^{\text {th }}\right.$ ed.). McGraw-Hill Companies, Inc: Boston.

Purwanto, Evanthe. 2015. Pengaruh biblioptherapy terhadap psychological wellbeing perempuan lajang. Jurnal Ilmiah Mahasiswa Universitas Surabaya, 4(1), 126.

Ryff, C. D. \& Keyes, C. L. M. 1995. The structure of psychological well-being revisited. Journal of Personality and Social Psychology, 69(2), 719.

Ryff, C. D. 1989. Happiness is everything, or is it? Explorations on the meaning of psychological well-being. Journal of Personality and Social Psychology, 57, 1069.

Saifullah. 2003. Buku ajar metodologi penelitian hukum. STAIN: Malang.

Santrock, John W. 2007. Adolescence, eleventh edition (Alih bahasa: benectine widyasinta). Jakarta: Erlangga.

Septiana, E., \& Syafiq, M. 2013. Identitas "lajang" (single identity) dan stigma: studi fenomenologi wanita lajang di Surabaya. Jurnal Psikologi Teori \& Terapan, 4(1), 71-86.

Shapiro, A., \& Keyes, C. L. M. (2008). Marital status and social well-being: are the married always better off?. Journal Social Indicators Research, 88(2), 329-346. 
Soekanto, Soerjono. 2006. Pengantar penelitian hukum. Penerbit Universitas Indonesia (UIPress).

Sugiyono. 2012. Metode penelitian kuantitatif kualitatif dan R\&D. Bandung: Alfabeta.

Sugiyono. 2014. Metode penelitian manajemen. Bandung: Alfabeta. 